\title{
Nonlinear soil-pile-structure interaction for midrise STMD buildings
}

\author{
Mohammad Ghorbanzadeh ${ }^{1 *(D)}$, Eris $\operatorname{Uygar}^{2}$ (D), Serhan Sensoy ${ }^{3}$ (D) \\ ${ }^{1}$ Department of Civil Engineering, Eastern Mediterranean University, 99628, Famagusta, North Cyprus, via \\ Mersin 10, Turkey, mohammad.ghorbanzadeh@cc.emu.edu.tr \\ ${ }^{2}$ Department of Civil Engineering, Eastern Mediterranean University, 99628, Famagusta, North Cyprus, via \\ Mersin 10, Turkey \\ ${ }^{3}$ Department of Civil Engineering, Eastern Mediterranean University, 99628, Famagusta, North Cyprus, via \\ Mersin 10, Turkey
}

Geliş / Received: 13/04/2021, Kabul / Accepted: 12/05/2021

\begin{abstract}
One of the effective vibration control systems used for structures is the semi active tuned mass damper (STMD), which is popular since it is reliable and simple. STMD characteristics in the design for piled foundations were usually obtained by modelling the foundation raft only to incorporate the soil structure interaction (SSI). However, as it proposed in the recent studies the role of SSI and simulation of piled raft in the analyses proved to be very important in the determination of the STMD parameters. Hence, in this study, efficiency of STMD with respect to the control of seismic response of the structure, was studied by considering the soil-pile-structure interaction (SPSI). Nonlinear time history analysis was applied for a three-layered soil profile including pile foundations by using the well-known substructure (spring) model under two different ground motion records. In order to increase the accuracy of the results, soil profile with piles and building structure with STMD were considered all at once in a single model under the action of seismic loading, named as direct method. P-Y curves which were suggested by American Petroleum Institute (API) were used in the spring method for simulating soil-pile-structure interaction. The results showed that, adjusting the STMD characterizations on piled structures without considering the soil-pile-structure interaction may result to ineffective control of the seismic vibration and in the worst case may lead to amplification of the vibration of buildings.
\end{abstract}

Keywords: SPSI interaction, Vibration control, STMD, Spring method, API curves.

Orta Yükseklikteki STMD’li Yapılar için Doğrusal Olmayan Zemin-Kazıkı Temel-Yapı Etkileşimi

Öz

Yapılardaki sismik titreşim kontrolü ile ilgili en etkin araçlardan biri de yapı içerisindeki enerji sönümlemesi için kullanılan sönümleme cihazlarıdır. Bunlar içerisinde, yarı-ayarlanabilir kütle sönümleme cihazları (STMD) güvenilirlikleri ve basitlikleri açılarından sıkılıkla kullanılır. Kazıklı temelleri olan yapılarda STMD cihazlarının karakteristik özellikleri birçok araştırmacı tarafından zemin yapı etkileşimi değerlendirilmeden tanımlanmıştır. Ancak son yıllarda yapılan çalışmalarda da belirtildiği gibi, kazıklı temellerin analiz sonuçlarındaki rolünün çok önemli olduğu ispatlanmıştır. Dolayısı ile bu çalışmada, STMD etkinlği zeminkazık temel-yapı etkileşimi (SPSI) gözününde bulundurularak değerlendirilmiştir. İki değişik zemin hareket kayıdı kullanılarak yay modeli ile katmanlı bir zeminde kazık temel davranışı doğrusal olmayan zaman analizi yöntemi ile uygulanmıştır. Sonuçların doğruluk derecesini artırmak için zemin, kazıklı temel ve yapı tek bir modelde birarada olmak kaydı ile sisimik yükleme etkisi direk yöntem adı verilen analiz yöntemi ile uygulanmıştır. SPSI simule edilirken kullanılan yay modelinde Amerikan Petrol Enstitüsü (API) tarafindan önerilen P-Y eğrileri kullanılmıştır. Sonuçlar STMD karakteristiklerinin ayarı yapılırken SPSI gözönünde bulundurulmadığında sismik titreşimin etken bir şekilde kontrol edilemediğini ve ayrıca bu sebepten dolayı titreşimi artırabileceğini dahi göstermiş̧ir.

\footnotetext{
*CorrespondingAuthor:mohammad.ghorbanzadeh@cc.emu.edu.tr
} 
Anahtar Kelimeler: Zemin-kazıklı temel-yapı etkileşimi, titreşim kontrolü, yarı ayarlanabilir kütle sönümleme cihazı, yay yöntemi, API eğrileri.

\section{Introduction}

Tuned Mass Damper (TMD) is one of the passive dampers which is commonly employed for mitigating the seismic vibration of structures. Many researches have proven capability and advantages of the use of TMD to control vibration against lateral loading such as earthquake or wind (Arfiadi and Hadi, 2011; Farghali, 2012; Mohebbi, 2013; Mohebbi and Alesh Nabidoust, 2018; Polat, 2019). However, due to detuning of TMD when the structures undergo severe earthquakes, semi-active (STMD) or active tuned mass dampers (ATMD) were also developed (Eason et al., 2013; Kaveh et al., 2015; Bakhshinezhad and Mohebbi, 2019; Talib et al., 2019; Akyürek et al., 2019; Khatibinia et al., 2020). Amongst these, semi active tuned mass damper (STMD) provides flexibility due to lower power consumption and changeable parameters during the earthquakes.

Some researchers have investigated the characteristics of STMD assuming fixed support at the base of structures and ignored the soil-structure interaction (SSI) effect on lateral structural behavior (Chen, D., and Wu, N. 2001; Elias, S., and Matsagar, V. 2017; Lu, Z. et al.2018; Yang, $\mathrm{Z}$., and $\mathrm{Li}, \mathrm{X}$. 2017). They reported the damper parameters as a result of this assumption was optimized. Also there are other studies such as the one carried out by Greco and Marano (2013), in which the performance of TMD is investigated ignoring the SSI. The results in Greco and Marano (2013) indicated that the energy criterion was significantly decreased with the use of TMD.

Foundations can settle and rotate under the loads based on mobilisation of the ground reaction and foundation \& structural stiffness, which altogether form the SSI. Hence, it is necessary to consider the SSI for the characterisation of the dampers.

Recently, several researches investigated the soil-structure effect on TMD characteristics. Farshidianfar and Soheili (2013) applied effective different optimization algorithm such as artificial bee colony and ant colony optimization to find optimum tuned TMD by including the SSI. Kamgar et al. (2019) revealed that considering the soil flexibility, can considerably influence the TMD adjustment by addressing the design procedure of displacement and acceleration criterion of structures.

Soheili et al. (2020) considered the effect of TMD on high-rise buildings particularly on drift criteria of structure including three different soil types by using ant colony algorithm to obtain proper parameters for TMD. Result demonstrated that using TMD leads to decrease the drift of building intensively.

Hence, it seems that soil-structure interaction will be altered the STMD setting. Accordingly, in this study, three layers soil profile including piles were considered to the midrise building which was equipped with semi active tuned mass damper. For simulating the soil-pile-structure interaction, well-known API recommendation (2007) curves (p-y) were applied through the spring method.

For obtaining the accurate result, soil block and superstructure were modelled in one stage and nonlinear time history analysis were done under two record motions. For explaining the SPSI 
effect on dynamic performance of structure, the acceleration and displacement criterion response of structure were evaluated and discussed.

\section{Substructure Model of the building}

A two-dimensional substructure model formed of 4 bay, 5 storey STMD steel building founded on a multi-layered soil profile was modelled. The pile foundations were embedded in soil block and their interaction with the ground and the superstructure was considered in the analyses.

\subsection{Ground model}

A thick deposit of Sand with varying relative density, shear strength and stiffness was considered as the soil profile. The SAND deposit is $18 \mathrm{~m}$ depth and comprised of three layers; $5 \mathrm{~m}$ depth of loose Sand underlain by $8 \mathrm{~m}$ depth of medium dense Sand and $5 \mathrm{~m}$ depth of medium dense to dense Sand. The geotechnical parameters used for the soil profile is presened in Table 1 .

Initially, site response analysis was conducted to determine displacements due to gravity loading, and the stress state in the soil profile was initialized. In the proceeding stages of the analyses, these initial displacements were disregarded to focus on the changes in due to seismic loading.

Table 1 Soil properties

\begin{tabular}{cccccc}
\hline Soil type & $\begin{array}{c}\text { Depth } \\
(\mathrm{m})\end{array}$ & $\begin{array}{c}\text { Shear } \\
\text { modulus } \\
\mathrm{G}(\mathrm{MPa})\end{array}$ & $\begin{array}{c}\text { Bulk } \\
\text { modulus } \\
\mathrm{B}(\mathrm{MPa})\end{array}$ & $\begin{array}{c}\text { Friction } \\
\text { angle } \\
\phi^{\prime}\end{array}$ & $\begin{array}{c}\text { Mass } \\
\text { density } \\
\rho\left(\mathrm{t} / \mathrm{m}^{3}\right)\end{array}$ \\
\hline $\begin{array}{c}\text { Loose } \\
\text { SAND }\end{array}$ & 5 & 46.9 & 125.1 & 25.4 & 1.94 \\
\hline $\begin{array}{c}\text { Medium } \\
\text { dense }\end{array}$ & 8 & 73.7 & 196.8 & 30.3 & 1.99 \\
SAND & & & & & \\
\hline $\begin{array}{c}\text { Medium } \\
\text { dense to } \\
\text { dense }\end{array}$ & 5 & 119.9 & 298.3 & 42.2 & 2.06 \\
SAND & & & & & \\
\hline
\end{tabular}

\subsection{Pile group}

Five steel pipe piles with $1.2 \mathrm{~m}$ diameter and $15 \mathrm{~m}$ length installed at $6 \mathrm{~m}$ centre to centre spacing were placed in soil block for modelling of the pile group. Following the American Petroleum Institute (API) recommendation (2007) and Ghorbanzadeh et al. (2021), the p-y, q$\mathrm{z}$, and $\mathrm{t}-\mathrm{z}$ nonlinear backbone curves were derived using Equation 1.

$$
\widehat{\mathrm{P}}=1.287 \mathrm{p}_{\mathrm{u}} \tanh \left(\frac{\mathrm{kH} \mathrm{y}}{1.287 \mathrm{p}_{\mathrm{u}}}\right)
$$

where,

$\widehat{\mathrm{P}}$ is the mobilised lateral resistance of single pile, which is obtained as a function of the horizontal pile displacement $\mathrm{H}_{\mathrm{y}}, \mathrm{k}$ is the modulus of subgrade reaction dependent on the internal angle of friction, and the ultimate soil lateral resistance is $p_{u}$, which can be obtained for wedge failure or flow failure mechanism derived from API recommendation (2007), and 1.287 is a 
coefficient related to cyclic loading, which was defined by Ghorbanzadeh et al. (2021) for midrise STMD structures.

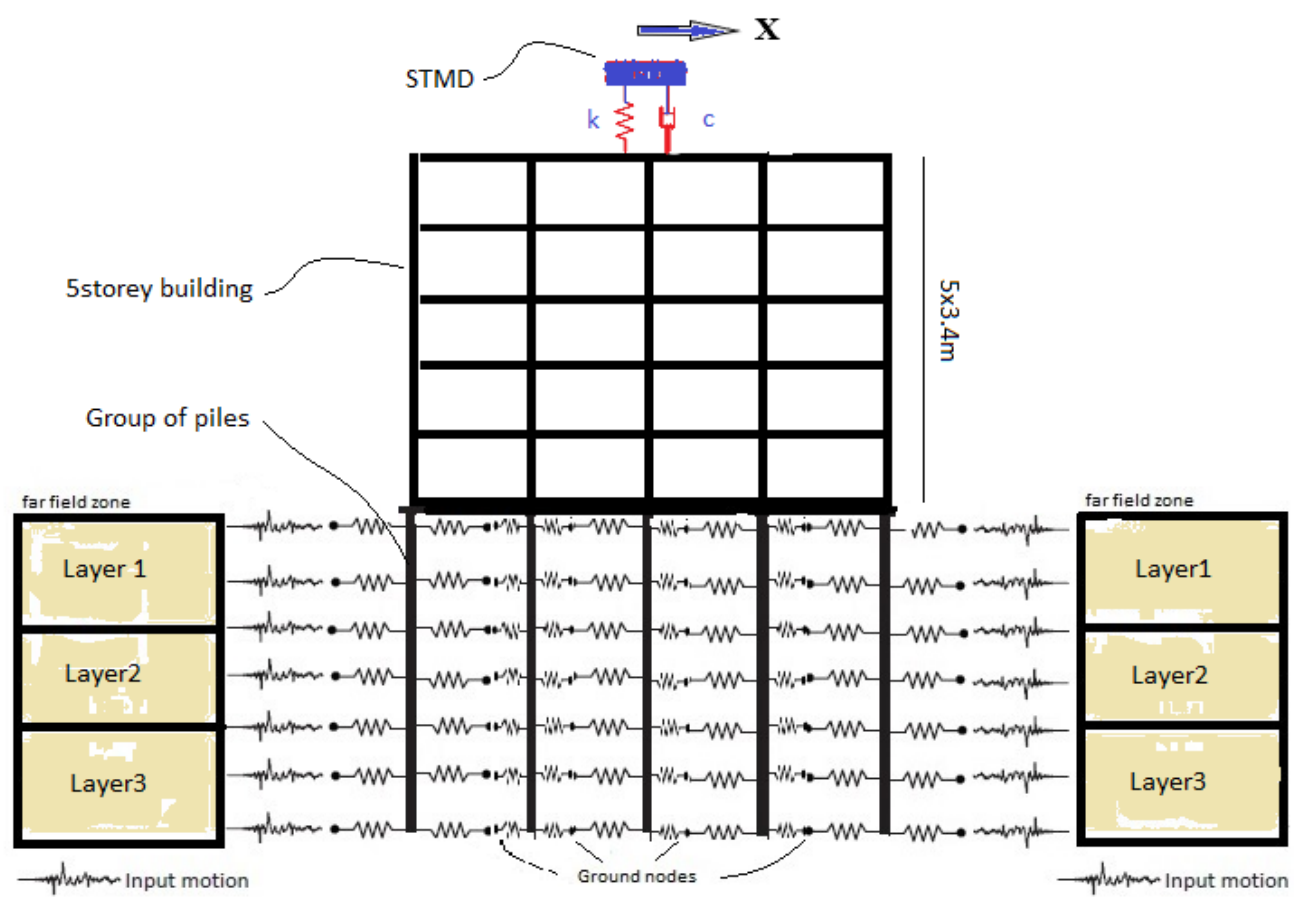

Figure 1 Schematiccal presentation of the entire model

The resulting are further utilized in the model file for simulation of the soil-pile-structure interaction.

\subsection{Superstructure with STMD}

For superstructure, a 5 storey steel building with 5\% structural damping ratio equipped with additional STMD was simulated.The superstructure has 4 bays with storey height of $3.4 \mathrm{~m}$ and span length of $6 \mathrm{~m}$. For columns box sections of $400 \times 30$ and $350 \times 25$, and for beams IPE270, IPE320 sections with St37 grades of steel were used. In addition, the properties of STMD installed on top of the building are; mass ratio $2 \%$, frequency ratio $9.03 \mathrm{rad} / \mathrm{s}$ with tuned damping ratio. On-Off displacement base Groundhook Algorithm, which was recommended by Koo and Setareh, (2004) was used to catch the optimum damping ratio of STMD on top of the building during seismic loading. All structural parts, soil block, pile group and the STMD are simulated in one region using the Open System for Earthquake Engineering Simulation (OpenSees) computer program (McKenna and Fenves, 2001). Figure 1 shows the schematiccally presentation of the entire model.

\subsection{Ground acceleration}

Two ground accelerations, near-field and far-field categories were chosen as record motions to be applied at the base of structure. The summary of data characteristics from chosen earthquakes Loma Prieta 1989 and Superstition 1987 were presented in Table 2. 
Table 2 Summary of data characteristics from chosen earthquakes Loma Prieta 1989 and Superstition 1987

\begin{tabular}{c|ccccc}
\multicolumn{1}{c}{ Earthquake } & Station & M & Dur.[s] & PGA[g] & situation \\
\hline Loma Prieta 1989 & Gilory array & 7.1 & 25 & 0.966 & Near- fault \\
Superstition hills 1987 & Niland-fire station & 6.6 & 22 & 0.136 & Far-fault
\end{tabular}

\section{Results and Discussion}

Nonlinear time history analysis for Superstition 1987 and Loma Prieta 1989 records were used to perform seismic analysis for the model considered. The criteria chosen for comparison of the analysis results were acceleration, displacement, and velocity responses at top of the structure. These results were used to evaluate the STMD performance with and without soil-pilestructure-interaction.

Figure 2 presents the acceleration time history plots for the superstructıre with and without STMD ignoring the soil-pile-structure-interaction (SPSI). As it was indicated by the results, by considering the fixed base and ignoring the SPSI, the STMD use led to a reduction in the maximum acceleration by $28 \%$ in Superstition and $36 \%$ in Loma earthquakes respectively. Therefore, by ignoring the SPSI, STMD worked very efficiently to reduce the peak acceleration, in which case the transfer of vibration from the fixed base was lower. In comparison, as presented in Figure 3, simulation of SPSI without STMD provided an acceleration increase of $57 \%$ and $33 \%$ for Superstition and Loma earthquakes, respectively. With the inclusion of the ground model and the piled foundations, the ground acceleration applied at the bedrock level were amplified.

In addition, Figure 3 demonstrates that the STMD use has led to a reduction of $18 \%$ and $9 \%$ in the maximum acceleration response for Superstition and Loma earthquakes, respectively.

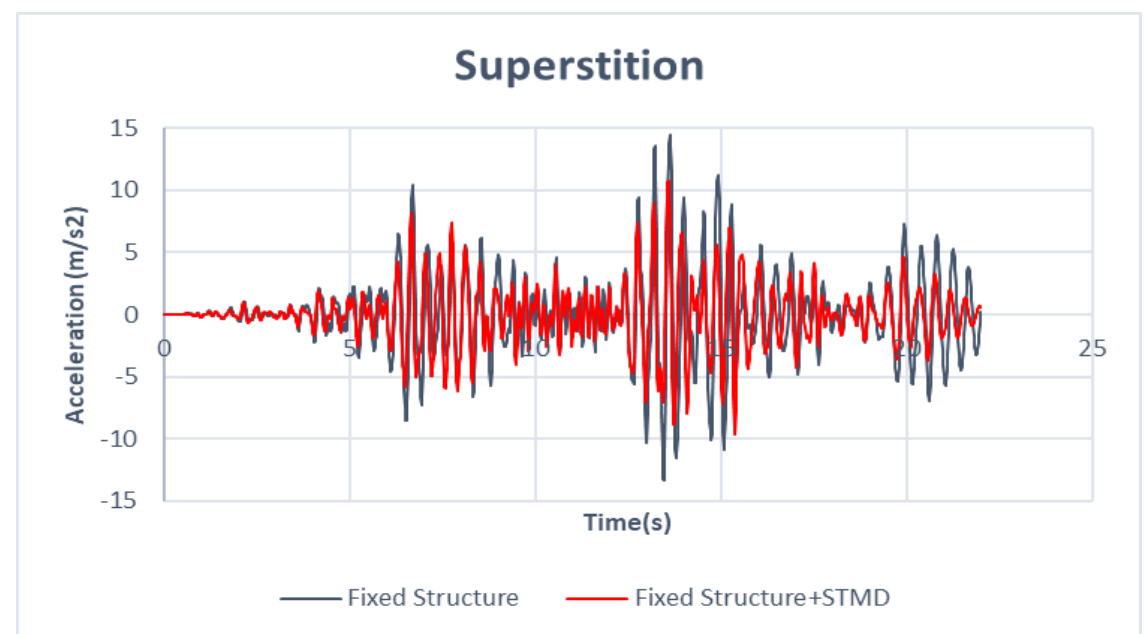

Figure 2 Acceleration time history of fixed base structure responses with and without STMD under Superstition and Loma record motions (continued on the next page) 


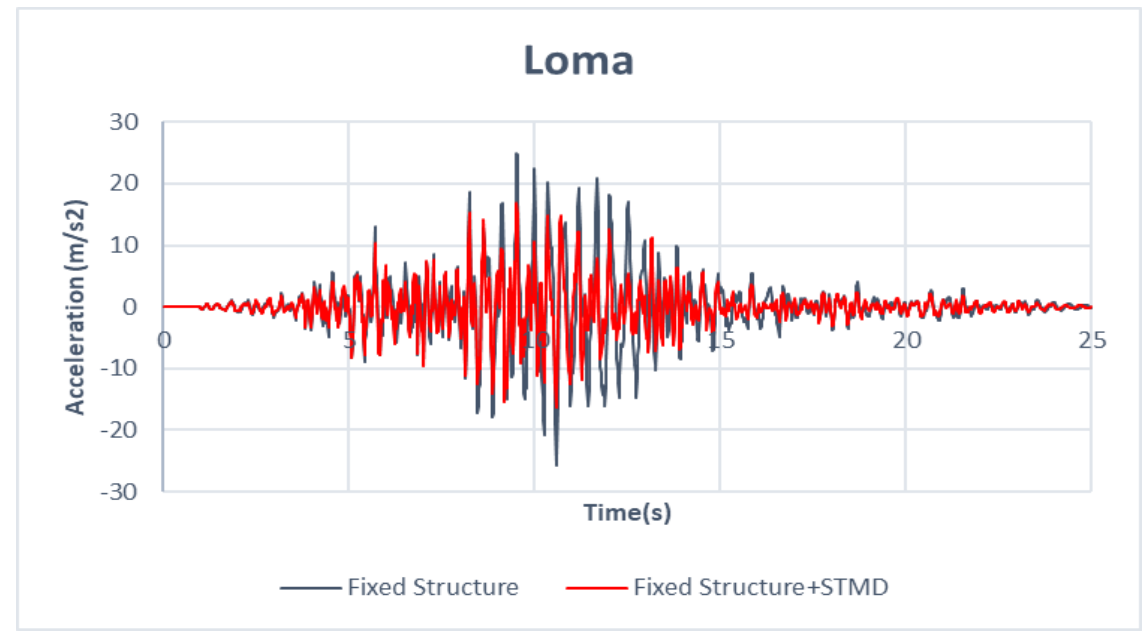

Figure 2 continu'ed

Further to these, by comparing Figure 2 and Figure 3, it can also be concluded that; (i) the max acceleration criteria at top of the structure significantly increased by incorporating the SPSI interaction, (ii) by considering the SPSI effect, the STMD efficiency was reduced by $40 \%$ and $75 \%$ for Superstition and Loma earthquakes, respectively. In summary, the use of STMD is still useful to reduce peak acceleration with and without SPSI.

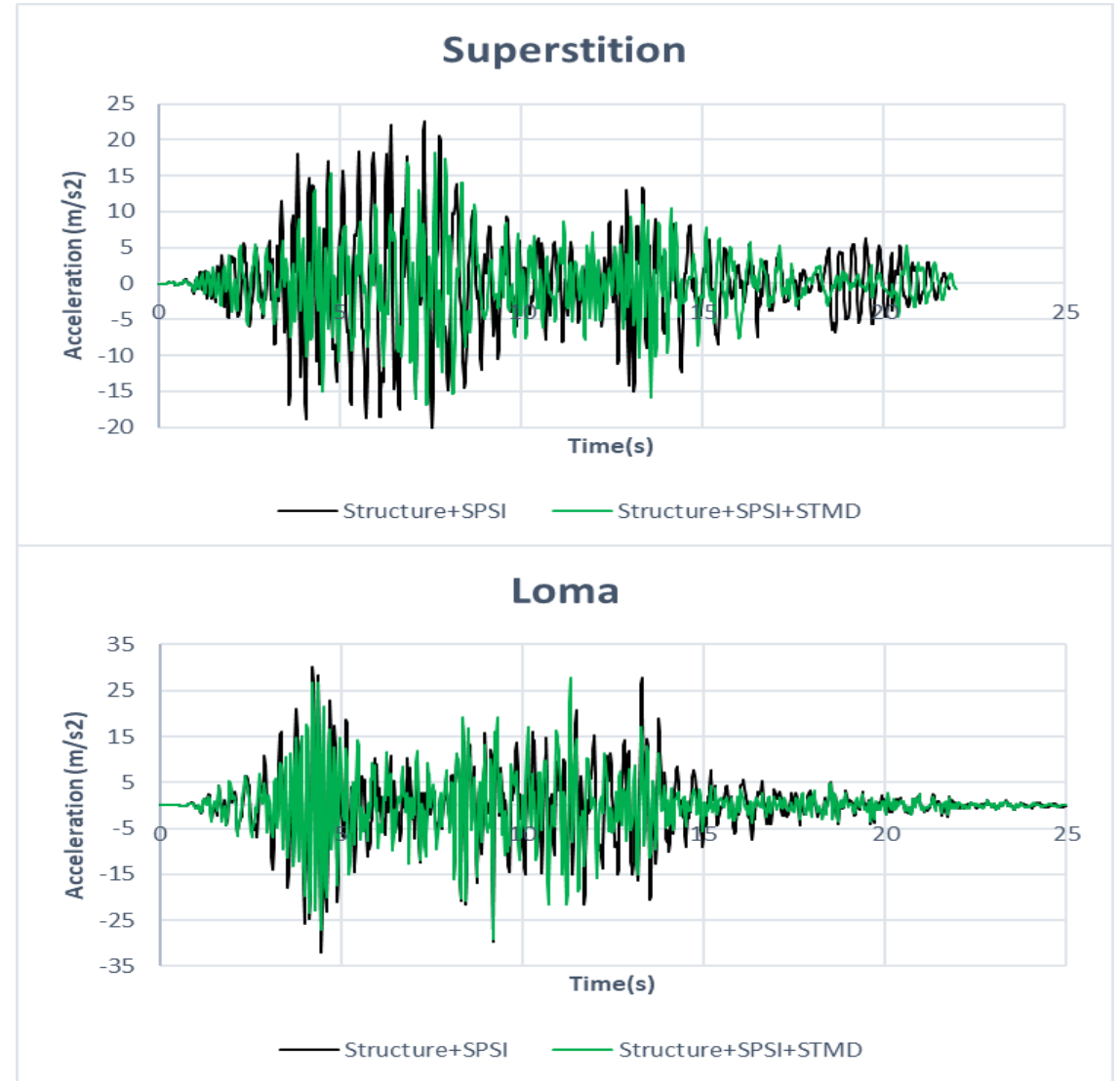

Figure 3 Acceleration time history of structure responses including SPSI with and without STMD under Superstition and Loma record motions 

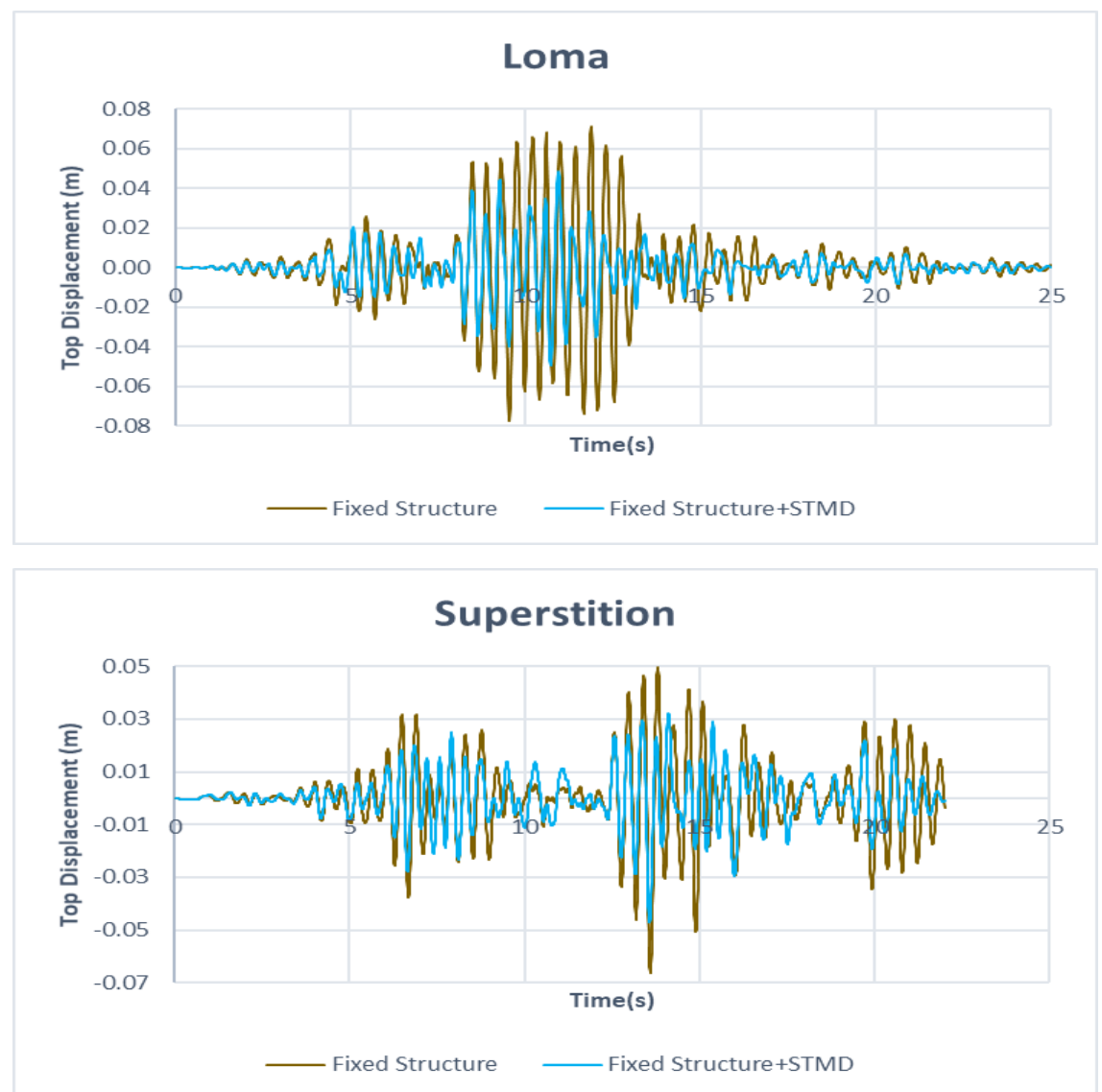

Figure 4 Top displacement time history of fixed base structure responses with and without STMD under Superstition and Loma record motions.

Top displacement criteria is also investigated to evaluate accurately the STMD performance with respect to considering SPSI. Displacement time history of structure ignoring the SPSI and fixed base assumption under two record motions (Superstition and Loma) are displayed in Figure 4. The displacement response of the structure with STMD was reduced by $28 \%$ for Superstition and $36 \%$ for Loma excitations, which were deemed to be acceptable for reduction of the top displacement criteria. The STMD helped dampening the top displacement by negating some of the vibrational effects.

Figure 5 shows the top displacement response of controlled and uncontrolled structure by considering the soil-pile-structure-interaction. The results show that although STMD reduces acceleration when SPSI was ignored, when SPSI was taken into account STMD failed to reduce displacement but increased it by $4.5 \%$ and $3 \%$ under Superstition and Loma excitation records, respectively. It means, STMD negatively affected displacement response of structure under earthquakes. In addition, the displacement response of the model was greatly increased under Superstition and Loma excitation records (260\% and $111 \%$, respectively). 

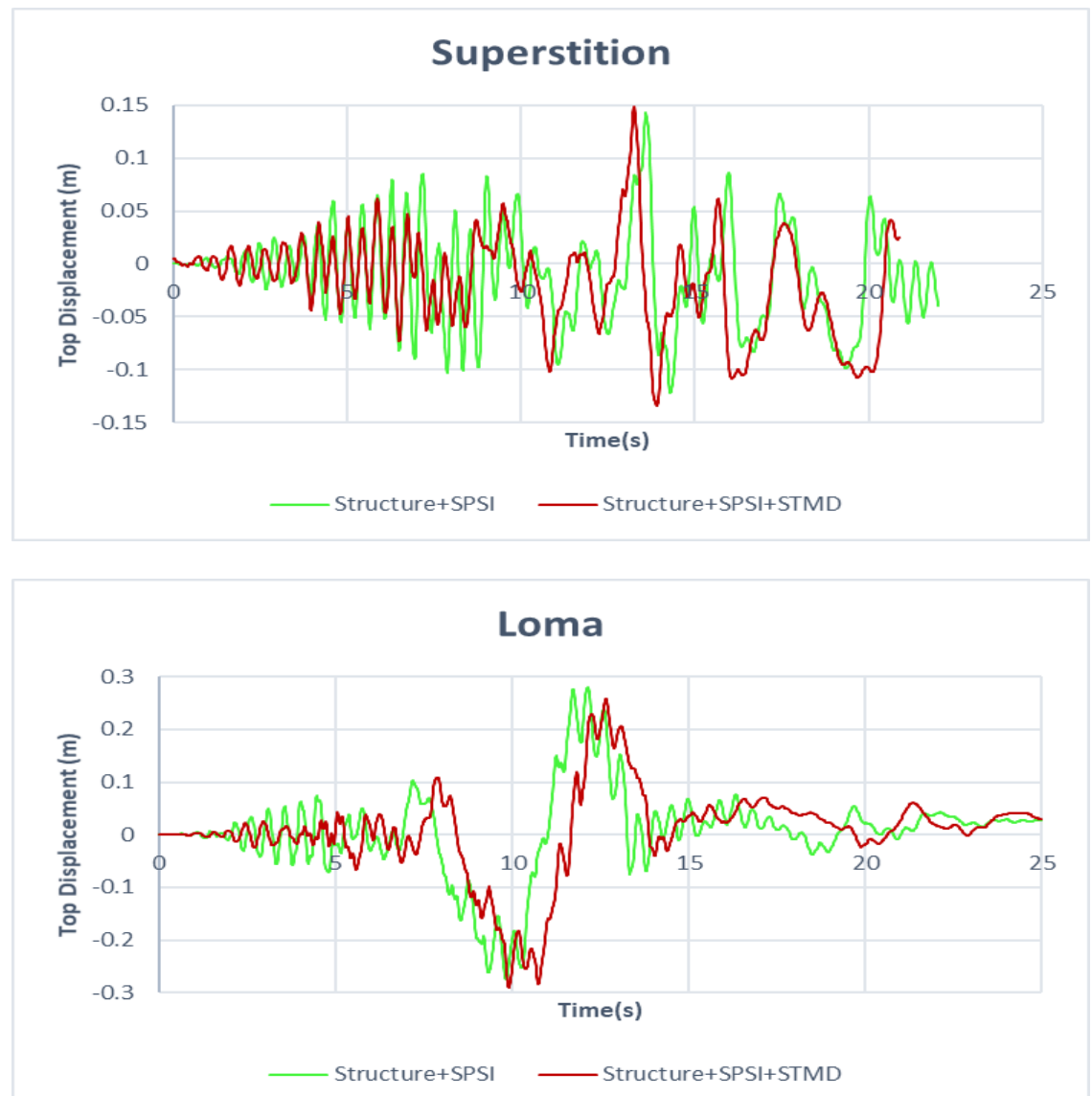

Figure 5 Top displacement time history of structure responses including SPSI with and without STMD under Superstition and Loma record motions

Velocity response at top of the structure presented in Figure 6 (without considering the SPSI) and Figure 7 (including SPSI) for Superstition and Loma earthquakes separately. As Figure 6 shows, STMD could reduce the response by $45 \%$ for Loma and $49 \%$ for Superstition when fixed base assumption was considered. Hence, it seems that STMD performed better and reduced the velocity response more rather than acceleration or displacement responses.

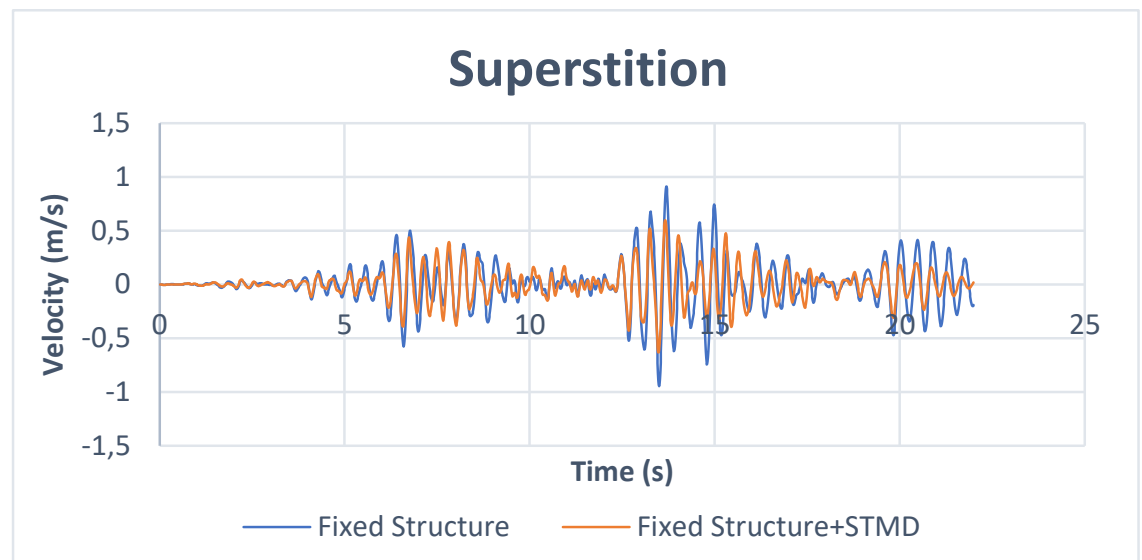

Figure 6 Velocity time history of fixed base structure responses with and without STMD under Superstition and Loma record motions. (continued on the next page) 


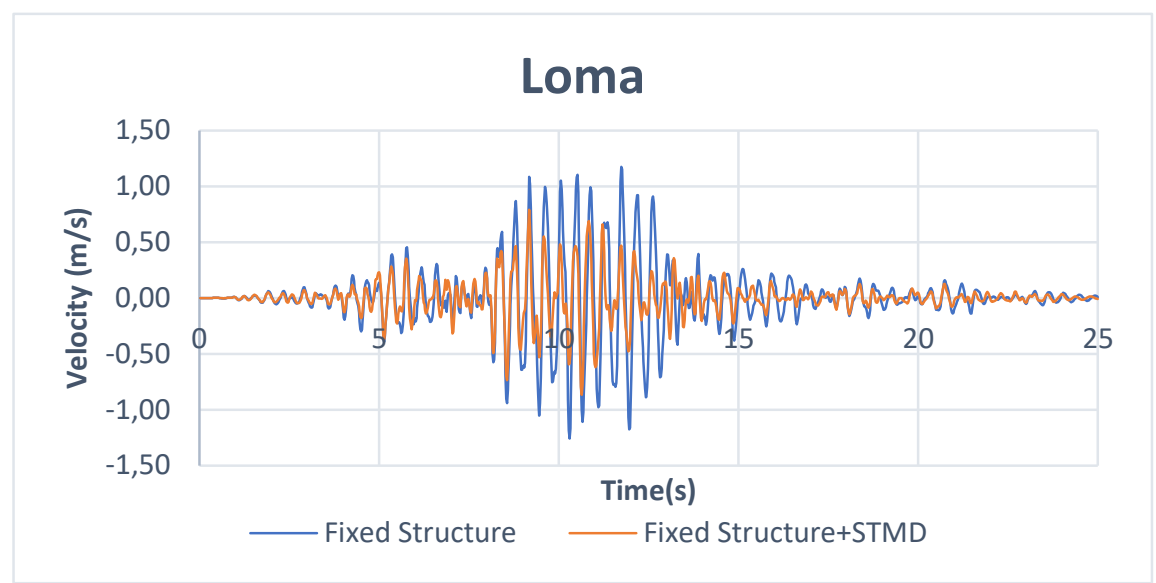

Figure 6 continu'ed

The velocity response shown in Figure 7, which includes SPSI and soil flexibility added to the structure was used to evaluate STMD performance. In this case, altough the STMD efficiency was decreased by including SPSI, the result showed that it is still useful for control of velocity respone of structure. As Figure 7 presents, the reduction levels are $68 \%$ for Loma and $45 \%$ for Superstition earthquakes. Therefore, using STMD in structure shows acceptable attitude for reducing the velocity response with and without consideration of SPSI.

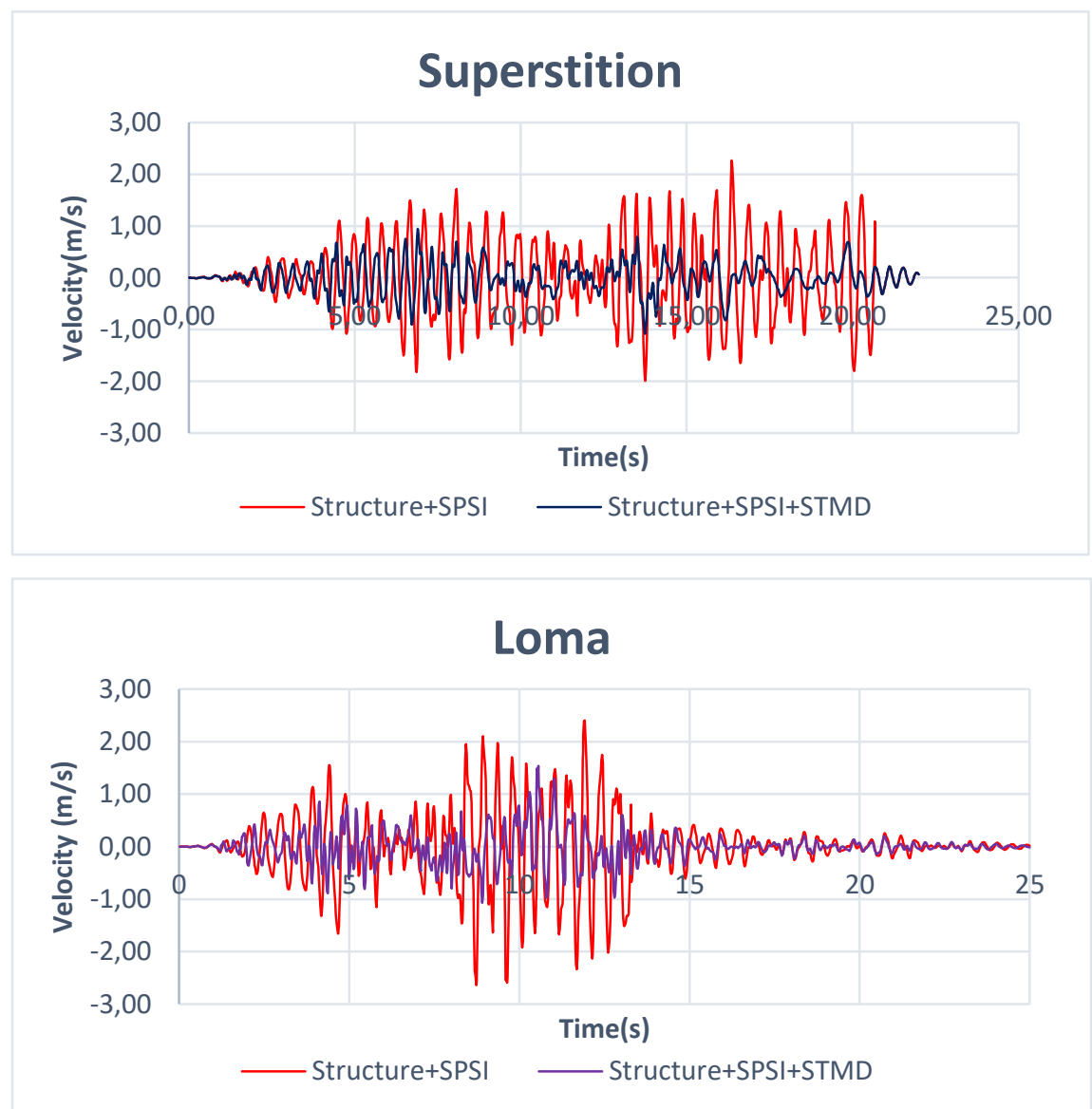

Figure 7 Velocity time history of structure responses including SPSI with and without STMD under Superstition and Loma record motions. 


\section{Conclusions and Recommendations}

This paper aimed to evaluate the semi active tuned mass damper considered for a midrise structure. In order to achieve this, acceleration response and displacement response with and without soil-pile-structure-interaction were analyzed. Nonlinear time history analysis were performed to investigate the dynamic response of the 5 story building with and without STMD, and also by considering fixed base and piled raft foundation, using the well-known substructure (spring) methodology under two earthquakes.

The comparison of the results revealed that;

- Although, using STMD on fixed base structure seems to act desirably and reasonably to reduce acceleration and displacement response of the structure for structures supported by group of piles, it can also have a reverse effect on the maximum acceleration response.

- For improvement of the STMD efficiency regarding the vibration control of structure, SPSI should be considered for structures with piled foundations.

- The STMD characterization should be strictly performed considering SPSI analyses to ensure optimal parameters were assigned.

\section{References}

Arfiadi, Y and Hadi M. N. S. 2011. Optimum placement and properties of tuned mass dampers using hybrid genetic algorithm, Int J Optim Civil Eng; 1(1): 167-87.

Farghali, A. A. 2012. Optimum design of TMD system for tall buildings, Int J Optim Civil Eng; 2(4): 511-32.

Mohebbi, M. and Alesh Nabidoust N. 2018. The capability of optimal single and multiple tuned mass dampers under multiple earthquakes, Int J Optim Civil Eng; 8(3): 469-88.

Mohebbi, M. 2013. Minimizing Hankel's norm as design criterion of multiple tuned mass dampers, Int J Optim Civil Eng; 3(2): 271-88.

Polat, H. İ. 2019. Betonarme Bir Yapıda Geleneksel Yöntem ve Taban İzolatörü Kullanımının Karş1laştırmalı Analizi, Eur. J. Sci.Technol.43-54. https://doi.org/10.31590/ejosat.495856.

Eason R. P., Sun C, Nagarajaiah S, Dick AJ. 2013. Attenuation of a linear oscillator using a nonlinear and semi-active tuned mass damper in series, $J$ Sound Vib; 332(1): 154-66.

Kaveh A., Pirgholizadeh S, Khadem Hosseini O. 2015. Semi-active tuned mass damper performance with optimized fuzzy controller using css algorithm, Asian J Civil Eng ; 16(5): 587-606.

Bakhshinezhad S., Mohebbi M. 2019. Fragility curves for structures equipped with optimal SATMDs, Int J Optim Civil Eng; 9(3): 437-455.

Khatibinia M, Mahmoudi M, Eliasi H. 2020. Optimal sliding mode control for seismic control of buildings equipped with ATMD, Int J Optim Civil Eng; 10(1) 1-15. 
Akyürek, O., Suksawang N, Go, T. H., and Tekeli, H. 2019. Performance evaluation of a reinforced concrete building strengthened respectively by the infill wall, active and passive tuned mass damper under seismic load. Comput Struct; 223:106097.

Talib, E., Shin, J. H, and Kwak, M. K. 2019. Designing multi-input multi-output modal-space negative acceleration feedback control for vibration suppression of structures using active mass dampers. J Sound Vib; 439:77-98.

Chen, G. D., \& Wu, J. N. 2001. Optimal placement of multiple tune mass dampers for seismic structures. Journal of Structural Engineering,127(9),1054-1062.

Elias, S., \& Matsagar, V. 2017. Research developments in vibration control of structures using passive tuned mass dampers. Annual Reviews in Control, 44, 129-156. doi:10.1016/j.arcontrol.2017.09.015.

Yang, Y.Z., \& Li, C. X. 2017. Performance of tuned tandem mass dampers for structures under the ground acceleration. Structural Control and Health Monitoring, 24(10), e1974. doi:10.1002/stc.1974.

Lu, Z., Chen, X. Y., \& Zhou, Y. 2018. An equivalent method for optimisation of particle tuned mass damper based on experimental parametric study. Journal of Sound and Vibration,419,571-584.

Greco, R., and Marano, G. C. 2013. Optimum design of tuned mass dampers by displacement and energy perspectives, Soil Dyn.Earthq.Eng.49243.253.ttps://doi.org/10.1016/j.soildyn.2013.02.013.

Farshidianfar, A. and Soheili, S. 2013. Optimization of TMD parameters for earthquake vibrations of tall buildings including soil structure interaction, Int J Optim Civil Eng; 3(3): 40929.

Kamgar, R, Khatibinia M. and Khatibinia M. 2019. Optimization criteria for design of tuned mass dampers including soil-structure interaction effect, Int J Optim Civil Eng; 9(2): 213-32.

Soheili, S., Zoka, H. and Abachizadeh, M. 2020. Tuned mass dampers for the drift reduction of structures with soil effects using ant colony optimization, Adv. Struct. Eng.. https://doi.org/10.1177/1369433220969023.

API. 2007. Recommended practice for planning, designing, and constructing fixed offshore plat forms, American Petroleum Institute.

Ghorbanzadeh, M., Uygar, E. and Sensoy, S. 2021. Lateral soil pile structure interaction assessment for semi active tuned mass damper buildings, Structures. 29 1362-1379. https://doi.org/10.1016/j.istruc.2020.12.020.

Koo J. H, and Setareh M. M. T. 2004. In search of suitable control methods for semi-active tuned vibration absorbers. J Vib Control 10 163-74.

McKenna, F. and Fenves, G. 2001. The OpenSees command language manual, Version 1.2, Pacific Earthquake Engineering Research Center, University of California, Berkeley, CA; http://opensees.berkeley.edu. 